\title{
LURAH DAN PARTISIPASI MASYARAKAT DALAM PEMBANGUNAN DI KELURAHAN CABENGE KECAMATAN LILIRILAU KABUPATEN SOPPENG
}

\author{
Alyas \\ Dosen STIE YPUP Makassar \\ E-mail: alyas1955@yahoo.com
}

\begin{abstract}
Abstrak: Penelitian ini bertujuan untuk mengetahui partisipasi masyarakat terhadap pembangunan di Kelurahan Cabenge. Penelitian ini menggunakan pendekatan penelitian kualitatif dengan memilih informan Kepala Lingkungan, Tokoh Masyarakat, Tokoh Agama, Tokoh Pemuda dan Kepala Keluarga. Teknik pengumpulan data yang dipergunakan yaitu observasi, wawancara, dan dokumentasi. Sedangkan analisis data digunakan adalah teknik analisis kualitatif yaitu dengan menggunakan langkah-langkah yaitu analisis reduksi dan analisis penyajian data. Hasil penelitian menunjukkan bahwa (1) Peranan Lurah secara persuasif dalam meningkatkan partisipasi masyarakat terhadap pembangunan dapat dilihat dari aktivitas lurah dengan cara membujuk dan mengajak masyarakat dan berhasil menggerakkan masyarakat untuk berpartisipasi terhadap pembangunan, (2) Peranan Lurah secara akomodatif dalam meningkatkan partisipasi masyarakat terhadap pembangunan yaitu memberikan informasi baik pada papan informasi di kelurahan maupun acara formal dan non formal mengenai masalah pembangunan sudah dapat mendorong masyarakat untuk berpartisipasi terhadap pembangunan, dan aktivitas lurah dalam menerima aspirasi masyarakat sudah cukup aktif tapi partisipasi masyarakat dalam mengeluarkan ide atau gagasan menyangkut masalah pembangunan masih cukup rendah dapat dilihat dari kurangnya masyarakat yang hadir dalam acara musrembang dan kurangnya masyarakat yang mengeluarkan ide atau aspirasinya, dan (3) Peranan Lurah Cabenge secara Dinamis Antisipatif dalam meningkatkan partisipasi masyarakat dalam pembangunan dapat dilihat dari aktivitas Lurah yang cukup berhasil dalam menggerakkan masyarakat memelihara hasil pembangunan.
\end{abstract}

Kata Kunci: Lurah, partisipasi masyarakat, pembangunan

\section{LURAH PARTICIPATION IN DEVELOPMENT OF VILLAGES CABENGE DISTRICT LILIRILAU SOPPENG}

Abstract: This study aimed to people participation toward development in the Village Cabenge. This study used a qualitative research approach to selecting informants Head of Environment, Community Leaders, Religious Leaders, Youth Leaders and headman. Data collection techniques used are observation, interviews, and documentation. While data analysis technique used is qualitative analysis by using the steps: analysis of the reduction and analysis of data presentation. The results showed that (1) The role of village chief persuasive in increasing people participation in the development can be seen from the headman activity by persuading and invite the community and managed to mobilize the community to participate to the development, (2) the role of headman in accommodating the increasing people participation in the development which provides good information on the information board in the village as well as formal and non-formal events on the issue of development has been to encourage the community to participate to the development and activity of headman in accepting people's aspirations are already quite active but public participation in issuing an idea or ideas concerning the problem of development is still quite low can be seen from the lack of people who attended the event and the lack of people ideas or aspirations, and (3) Role of Dynamically headman Cabenge Anticipatory in increasing community participation in development activities can be seen from the village chief who is quite successful in mobilizing communities maintain development results.

Keywords: Headman, community participation, development

\section{PENDAHULUAN}

Partispasi masyarakat merupakan salah satu alat ukur keberhasilan pembangunan. Partisipasi segenap lapisan masyarakat dalam pembangunan harus semakin luas dan merata, baik dalam memikul beban pembangunan maupun dalam mempertanggung jawabkan pelaksanaan pembangunan ataupun didalam menerima kembali hasil pembangunan.

Upaya meningkatkan partisipasi masyarakat dalam pembangunan bukan sekedar mengubah sikap, pendapat dan perilaku individu atau masyarakat melainkan perubahan masyarakat sebagai pemeran pembangunan, baik sebagai subjek maupun objek pembangunan. Namun dalam kenyataannya tumbuh dan meningkatnya partisipasi masyarakat dalam pembangunan belum mencapai sasaran yang diinginkan. Gejala ini selalu timbul karena selama ini belum digalakkan dan ditanamkan pada semua warga masyarakat agar berusaha atas kemampuan sendiri, percaya kepada diri sendiri dan pola yang membangkitkan inovasi.

Untuk menggerakkan roda kegiatan pembangunan termasuk menggerakkan partisipasi masyarakat di tingkat kelurahan, diperlukan pemimpin dengan integritas kepemimpinan yang handal agar dapat membina, mengarahkan, memimpin masyarakat menuju pada tercapainya tujuan penyelenggara pembangunan yang dicita-citakan. Kehadiran seorang pemimpin dengan kualitas kepemimpinan yang baik akan mampu menggerakkan partisipasi 
masyarakat sehingga pembangunan kelurahan akan dapat dilaksanakan dengan baik dan pada gilirannya pembangunan yang dicita-citakan akan terwujud.

Kepemimpinan menjadi faktor pertama keberhasilan pembangunan karena kepemimpinan meletakkan visi dan misi dari pembangunan. Administrator pembangunan bertugas melakukan rentetan usaha bersama dengan masyarakat dalam iklim yang demokratis untuk mengadakan perbaikan dan peningkatan tata kehidupan serta sarana kehidupan demi pencapaian kesejahteraan, kebaikan serta keadilan yang lebih merata. Pemimpin formal sebagai alat negara dalam proses administrasi negara khususnya dalam pembangunan nasional harus sanggup melancarkan jalannya administrasi secara maksimal sedangkan dalam proses teknis dan sosial, dia harus mampu menjalankan tugas-tugas sosio-teknis yang berkaitan dengan pembangunan manusia yaitu berkaitan dengan semua peralatan, sarana dan pembinaan segenap bakat potensi manusianya yang digerakkan demi tugas pembangunan bangsa.

Kepala Kelurahan dalam arti pemimpin pemerintahan di tingkat kelurahan berfungsi sebagai penanggung jawab utama di bidang pemerintahan dan pembangunan kemasyarakatan dimana lurah itu ditempatkan.

Mengingat kedudukan tersebut, Lurah mempunyai peranan penting yang sangat besar dalam usaha menumbuhkan dan menggerakkan partisipasi masyarakat dalam kegiatan pembangunan pada umumnya dan pembangunan di Wilayah Kelurahan khususnya. Apabila hal ini dapat ditumbuhkan dan ditingkatkan maka pada gilirannya tujuan pembangunan yang dicita-citakan akan lebih muda untuk diwujudkan.

Berdasarkan latar belakang yang telah dijelaskan diatas, maka rumusan masalah dalam penelitian ini adalah bagaimana pengaruh kepemimpinan lurah dalam menggerakkan partisipasi masyarakat terhadap pembangunan di Kelurahan Cabenge Kecamatan Lilirilau Kabupaten Soppeng? Adapun tujuan yang hendak dicapai dalam penelitian ini sesuai rumusan masalah yang telah ditetapkan adalah untuk mengetahui pengaruh kepemimpinan lurah dalam menggerakkan partisipasi masyarakat terhadap pembangunan di Kelurahan Cabenge.

\section{Partisipasi Masyarakat}

Partisipasi menurut Supriatna (1995:40) adalah “Kata partisipasi berasal dari bahasa Inggris participation dan katakerjanya participate artinya peran serta, ikut serta. Ikut mengambil bagian secara populer menjadi participation artinya peran atau ikut serta untuk mengambil bagian dalam kegiatan tertentu". Selanjutnya, Moeljarto (1987:136) mengemukakan bahwa "Partisipasi adalah pernyataan mental emosional seseorang dalam situasi kelompok yang mendorong mereka menyumbangkan daya pikiran dan perasaan mereka bagi tercapainya tujuan organisasi dan bersama-sama bertanggung jawab terhadap organisasi tersebut".

Secara teoris Kartini (2003:284) mengungkapkan bahwa "Partisipasi adalah ketertiban secara terbuka dan keikutsertaan. Keduanya mengandung kesamaan tetapi berbeda titik tekanannya. Keterlibatan secara terbuka menyangkut unsur-unsur yang terlibat, sedangkan keikutsertaan berbicara tentang bagaimana masyarakat terlibat".

Keterlibatan berarti peluang bagi siapa saja untuk mengamati kegiatan pembangunan, terutama manfaatnya untuk kelompok-kelompok masyarakat miskin, minoritas, rakyat kecil, perempuan dan kelompok marginal lainnya.

Voice (suara) berarti setiap warga mempunyai hak dan ruang untuk menyampaikan suaranya dalam proses pemerintahan. Pemerintah sebaiknya mengakomodasi setiap suara yang berkembang dalam masyarakat yang kemudian dijadikan sebagai basis pembuatan keputusan.

Bertolak dari pengertian partisipasi tersebut diatas maka terdapat 3 (tiga) aspek dalam partisipasi yaitu (1) Partisipasi menitikberatkan pada keterlibatan mental dan emosional, (2) Adanya keberanian untuk memberikan kontribusi, dan (3) Adanya keberanian untuk menerima tanggung jawab atau suatu usaha terbangkitkan.

Dengan demikian dari pengertian tersebut dapat ditarik kesimpulan bahwa partisipasi adalah keikutsertaan atau ikut serta seseorang/ sekelompok orang yang aktif untuk mengambil bagian dalam kegiatan bersama, baik secara fisik maupun mental emosional.

\section{Partisipasi Mayarakat dalam Pembangunan}

Partisipasi masyarakat dalam pembangunan merupakan aktualisasi dari kesediaan dan kemampuan anggota masyarakat untuk berkorban dan berkontribusi dalam implementasi program/proyek yang dilaksanakan. Dimaklumi bahwa anggaran pembangunan yang tersedia adalah relatif terbatas sedangkan program atau proyek pembangunan yang dibutuhkan (yang telah direncanakan) jumlahnya relatif banyak, maka perlu dilakukan peningkatan partisipasi masyarakat untuk menunjang implementasi pembangunan program/proyek yang dilaksanakan.

Ada beberapa alasan yang kuat perlunya masyarakat diajak untuk ikut berpartisipasi dalam pembangunan. Menurut Adisasmita (2006:36): "Alasan atau pertimbangan diajak berpartisipasi karena anggota masyarakat dianggap mereka mengetahui sepenuhnya tentang permasalahan dan kepentingan atau kebutuhan mereka meliputi; (1) Mereka memahami sesungguhnya tentang keadaan lingkungan sosial dan ekonomi masyarakat, (2) Mereka mampu menganalisa sebab dan akibat dari berbagai kejadian yang terjadi dalam masyarakat, (3) Mereka mampu merumuskan solusi untuk mengatasi permasalahan dan kendala yang dihadapi masyarakat, (4) Mereka mampu memanfaatkan Sumber Daya Pembangunan (SDA, SDM, dana, teknologi) yang dimiliki untuk meningkatkan produksi dan produktivitas dalam rangka mencapai sasaran pembangunan masyarakat, dan (5) Anggota masyarakat dengan upaya meningkatkan kemajuan dan kemampuan SDM-nya, sehingga dengan berlandaskan pada kepercayaan diri dan keswadayaan yang kuat mampu menghilangkan sebagian besar ketergantungan terhadap pihak luar".

Penggunaan istilah pembangunan kelurahan sering dipertukarkan dengan pembangunan pedesaan dalam konteks penelitianinidengankatalainistilahpembangunan 
kelurahan. Hal ini sebagaimana dikemukakan oleh Ndraha (1987:100) bahwa "Istilah pembangunan pedesaan saling dipertukarkan dengan istilah pembangunan kelurahan didalam batas-batas pengertian pembangunan masyarakat. Tentu saja pembangunan pedesaan sebagai metode dapat juga diterapkan pada pembangunan masyarakat didaerah perkotaan. Ini juga yang dijadikan landasan pembangunan desa didalam kota-kota di seluruh Indonesia dewasa ini”".

Dengan demikian, dapat dipahami bahwa istilah pembangunan desa merupakan satu kegiatan atau usaha pembangunan yang dilasanakan pula oleh masyarakat di pemerintahan tingkat kelurahan dalam rangka meningkatkan kesejahteraan masyarakat desa dan meletakkan dasar-dasar pembangunan secara sehat dan kuat. Hal ini juga sebagaimana yang dikemukakan oleh Marbun (1980:34) bahwa "Pembangunan desa merupakan suatu usaha pembangunan dari masyarakat dari unit pemerintahan rendah yang harus dilaksanakan dan dibina terus menerus, sistematis dan terarah sebagai suatu kesatuan dengan pembangunan regional/ daerah dan nasional".

Hubungan dari hal tersebut diatas, maka menurut Adisasmita (2006:135) mengatakan bahwa "Salah satu faktor keberhasilan pembangunan partisipatif adalah faktor kemampuan kepemimpinan dan respon anggota masyarakat yang dipimpinnya.. Kepemimpinan yang diperlukan yaitu: (1) Pemimpin yang persuasif yang dimaksudkanuntukmembujuk, meyakinkandanmengajak masyarakat untuk melakukan kegiatan pembangunan untuk meningkatkan kesejahteraan masyarakat, (2) Pemimpin yang akomodatif berani memiliki kemampuan untuk menyesuaikan, mendamaikan, memberikan informasi dan menampung berbagai keinginan masyarakat, sehingga dapat diarahkan dan dimanfaatkan untuk melakukan partisipasi pembangunan, dan (3) Dinamis Antisipatif dimaksudkan sebagai kemampuan menggerakkan kekuatan pengawasan dan kemampuan masyarakat melaksanakan partisipasi untuk mencapai tujuan dan sasaran pada masa depan".

Demikian juga yang dikemukakan oleh Moeljarto (1987:48) mengemukakan dalam Ensiklopedi pembangunan disebutkan bahwa "Partisipasi aktif segenap lapisan masyarakat dalam pembangunan harus semakin luas dan merata baik dalam memikul beban pembangunan maupun dalam pertanggungjawaban atas pelaksanaan pembangunan ataupun didalam menerima kembali hasil-hasil pembangunan".

Partisipasimasyarakatdalampembangunan tersebut diharapkan semakin luas dan merata, baik dalam memikul beban pembangunan, pertanggungjawaban atas pelaksanaannya maupun didalam menerima atau memelihara hasil-hasil pembangunan itu.

Berkaitandenganhaltersebutdiatas, Koentjaraningrat (1985:80) mengemukakan bahwa "Partisipasi masyarakat dalam pembangunan mempunyai 2 (dua) tipe, yaitu: (1) Partisipasi dalam aktivitas bersama dalam proyek-proyek pembangunan khusus sifatnya ialah bahwa rakyat ingin menyumbangkan tenaga harta benda berdasarkan atas keyakinan bahwa proyek tersebut akan bermanfaat bagi dirinya dan mereka akan berpartisipasi dengan semangat yang besar tanpa mengharapkan upah dan (2) Partisipasi sebagai individu diluar aktivitas bersama dalam pembangunan sifatnya tidak memerlukan suatu partisipasi atas perintah atau paksaan atasan tetapi selalu atas dasar kemauan sendiri.

Selanjutnya dikemukakan oleh Ndraha (1980:2) bahwa: "Partisipasimasyarakatdalamprosespembangunanmeliputi: (1) Partisipasi dalam memikul beban pembangunan yaitu (a) Beban fisik : biaya, tenaga, waktu, kehadiran, material, tanah, alat perlengkapan, sarana penunjang dan sebagainya yang memerlukan swadaya dan (b) Beban non fisik : tanggapan, saran, pendapat, pikiran, prakarsa, (2) Partisipasi dalam pertanggungjawaban pelaksanaan pembangunan yaitu (a) Pertanggungjawaban administrasi melalui Lembaga Ketahanan Masyarakat Desa (LKMD) dan (b) Kontrol sosial terhadap pelaksanaan pembangunan; (3) Partisipasi dalam menerima kembali hasil-hasil pembangunan yaitu (a) Penilaian sosial terhadap hasil (manfaat) pembangunan, (b) Pembangunan dan pengusahaan hasil pembangunan, (c) Perawatan dan pemeliharaan hasil pembangunan, dan (d) Pengembangan hasil pembangunan.

Berdasarkan penjelasan tersebut diatas, dapatlah dipahami bahwa partisipasi masyarakat pada hakekatnya tidak merupakan prilaku yang dapat dipaksakan dari luar tetapi tumbuh dari kesadaran sendiri tanpa disuruh atau diperintah oleh pihak lain. Masyarakat sendiri yang dikehendaki berinisiatif dan kreatif, terlibat secara fisik maupun non fisik dalam berbagai pelaksanaan mulai dari perencanaan, pelaksanaan dan pengawasan serta dalam menikmati hasil pembangunan dan memeliharanya. Oleh karena itu pula partisipasi masyarakat hanya akan timbul, bilamana kegiatan atau usaha yang dilakukan menyangkut atau sesuai dengan keinginan dan kebutuhan masyarakat.

\section{METODE}

Lokasi yang dijadikan objek penelitian oleh peneliti adalah Wilayah Kantor Kelurahan Cabenge Kecamatan Lilirilau Kabupaten Soppeng. Sedangkan pelaksanaannya yaitu bulan Maret sampai dengan April 2014. Penelitian ini menggunakan pendekatan penelitian kualitatif. Informan dalam penelitian adalah Kepala Lingkungan, Tokoh Masyarakat, Tokoh Agama, Tokoh Pemuda dan Kepala Keluarga. Teknik pengumpulan data yang dipergunakan yaitu observasi, wawancara, dan dokumentasi. Sedangkan analisis data digunakan adalah teknik analisis kualitatif yaitu dengan menggunakan langkah-langkah yaitu analisis reduksi dan analisis penyajian data.

\section{HASIL DAN PEMBAHASAN}

Kepemimpinan Lurah dalam konteks penelitian ini diukurdengan 3 (tiga) indikatoryakni kepemimpinan lurah dengan cara persuasif dalam menggerakkan partisipasi masyarakat terhadap pembangunan, kepemimpinan lurah dengan cara akomodatif dalam menggerakkan partisipasi masyarakat terhadap pembangunan dan kepemimpinan lurah dengan cara dinamis antisipatif dalam menggerakkan partisipasi masyarakat terhadap pembangunan. Ketiga indikator tersebut dapat diuraikan sebagai berikut:

PerananLurahSecara Persuasifdalam Meningkatkan Partisipasi Masyarakat terhadap Pembangunan 
Peranan Lurah secara persuasif dapat dilihat dari dua indikator yaitu dengan cara membujuk dan meyakinkan masyarakat tersebut ataukah dengan memberikan motivasi kepada masyarakat.

\section{a. Aktivitas atau kegiatan Lurah dalam membujuk dan meyakinkan masyarakat}

Aktifitas atau kegiatan lurah dalam membujuk dan meyakinkan masyarakat supaya dapat turut serta berpartisipasi dalam pembangunan merupakan suatu hal yang tidaklah mudah bagi seorang Kepala Kelurahan, lurah dalam membujuk dan meyakinkan masyarakat haruslah mengetahui dan mengenal lebih dekat karakteristik masyarakatnya yang berbeda antara kelompok masyarakat yang satu dengan kelompok masyarakat lainnya. Kelompok masyarakat yang berpendidikan tentu berbeda dengan kelompok masyarakat yang tidak berpendidikan dalam membujuk dan meyakinkannya.

Hasil wawancara penulis dengan Lurah Cabenge tanggal 20 Maret 2014 diperoleh informasi bahwa lurah dalam membujuk dan mengajak serta meyakinkan masyarakat agar dapat turut serta berpartisipasi dalam pembangunan dilakukan dengan cara berdialog langsung dengan warga masyarakat, serta dilakukan pada setiap kesempatan baik itu pada pertemuan-pertemuan formal baik itu rapat-rapat maupun pertemuan non formal lainnya. Aktivitas seperti ini menurutnya sudah merupakan kegiatan rutin dimana pada setiap kesempatan berbicara dia berusaha menyelipkan katakata ajakan atau bujukan kepada masyarakat agar turut berpartisipasi terhadap pembangunan. Lebih lanjut, menurut bapak Lurah Cabenge mengatakan bahwa cara seperti ini yaitu dengan membujuk dan mengajak masyarakat serta didukung dengan komunikasi yang baik dapat langsung menyentuh dan menggugah hati masyarakat untuk turut berpartisipasi terhadap pembangunan.

Aktivitas atau kegiatan yang dilakukan oleh Lurah Cabenge dengan cara membujuk dan mengajak serta meyakinkan masyarakat agar dapat berpartisipasi terhadap pembangunan mandapat respon yang positif dari warga masyarakat, hal ini sesuai dengan wawancara yang dilakukan oleh seorang tokoh masyarakat Kelurahan Cabenge yang mengatakan bahwa : "Saya sangat setuju sekali atas cara bapak Lurah Cabenge dalam membujuk dan meyakinkan kami untuk turut serta berpartisipasi terhadap pembangunan di kelurahan karena tidak semua lurah mau dan mampu melakukan hal seperti ini”. (Djaga : 21 Maret 2014)

Kegiatan lurah tersebut juga dirasakan efektif oleh sebagian masyarakat dalam menggerakkan partisipasi, masyarakat terhadap pembangunan, berdasarkan kesimpulan dari hasil wawancara kepada kepala keluarga diperoleh informasi cara mengajak, membujuk dan meyakinkan masyarakat sangat cocok diterapkan di wilayah Kelurahan Cabenge karena di Kelurahan Cabenge terdiri dari berbagai macam karakteristik yang berbeda-beda sehingga cara seperti itulah yang dirasakan masyarakat sangat efektif dilakukan. Sesuai dengan wawancara yang dilakukan oleh tokoh masyarakat yang mengatakan bahwa "di Kelurahan Cabenge ini terdiri atas berbagai macam suku yang ada disini, baik Suku Bugis, Suku Jawa maupun Orang Makassar yang berbeda-beda watak dan perilakunya sehingga untuk menggerakkan mereka salah satunya yaitu dengan membujuk dan meyakinkannya". (Baba Ismail : 24 Maret 2014)

Dari uraian di atas nampak bahwa masyarakat Kelurahan Cabenge merespon positif kegiatan bapak Lurah dalam menggerakkan partisipasi masyarakat terhadap pembangunan. Kelurahan Cabenge yang terdiri dari penduduk yang beraneka ragam karakteristik memerlukan cara atau metode tersendiri yang disesuaikan dengan watak ataupun perilaku individu masing-masing masyarakat tersebut. Karakteristik Suku Jawa tentulah sangat berbeda dengan masyarakat pribumi ataukah masyarakat yang berasal dari Suku Bugis ataukah masyarakat yang berasal dari Makassar. Oleh sebab itu dengan cara membujuk, mengajak dan meyakinkan mereka merupakan salah satu cara yang lebih baik untuk mendekati mereka serta mengajaknya turut serta berpartisipasi dalam pembangunan.

Namun tidak semua masyarakat menilai baik aktivitas atau kegiatan Lurah Cabenge tersebut, ada pula masyarakat yang berpendapat bahwa aktivitas lurah tersebut tidak efektif lagi dilakukan di zaman sekarang ini, masyarakat sekarang lebih banyak menuntut imbalan dalam melakukan sesuatu dibandingkan dengan hanya membujuk dan meyakinkan mereka. Hal ini berdasarkan wawancara dari salah seorang kepala keluarga yang mengatakan bahwa : "sebagian dari kami sekarang itu sudah susah digerakkan hanya mengandalkan bujukan, rayuan atau ajakan dari siapapun untuk berpartisipasi dalam pembangunan apalagi yang sampai mengorbankan biaya dan waktu di zaman yang serba tidak gratis lagi" (Asri, 26 Maret 2014)

Pada dasarnya memang kebutuhan manusia antara yang satu dengan yang lainnya berbedabeda, hal ini salah satu faktor penyebabnya adalah perbedaan tingkat ekonomi dan status dalam suatu masyarakat, jadi untuk menyatukan mereka dalam suatu tujuan tertentu khususnya menggerakkan mereka berpartisipasi dalam pembangunan bukanlah hal yang sangat mudah serta ditunjang dengan adanya pemimpin dalam hal ini kepala kelurahan sebagai seseorang yang memiliki kemampuan manajemen kepemimpinan sehingga dapat memberikan solusi yang terbaik dari permasalahan tersebut.

Disadari oleh bapak Lurah Cabenge berdasarkan wawancara yang dilakukan penulis tanggal 26 Maret 2014 bahwa dalam menggerakkan masyarakat untuk berpartisipasi terhadap pembangunan dengan cara hanya mengandalkan bujukan, rayuan, ajakan atau keyakinan merupakan suatu pekerjaan yang membutuhkan banyak pengorbanan baik itu waktu, tenaga maupun biaya sekalipun. Menanggapi jawaban dari wawancara dengan masyarakat tersebut bapak Lurah Cabenge membenarkan pernyataan tersebut menurutnya memang benar tidak semua masyarakat dapat menerima cara seperti ini karena kita tahu sendiri bahwa di Kelurahan Cabenge ini terdiri dari berbagai macam karakteristik dan latar belakang budaya yang berbeda-beda. Lebih 
lanjut dia mengatakan bahwa "kalau orang keras kita kerasi pasti diapun lebih keras tetapi kalau kita berikan kelembutan, kita rayu dia, kita ajak dengan cara yang baik-baik dan kita yakinkan dia, saya kira sangatlah mudah untuk menggerakkan terhadap pembangunan".

Seorang pemimpin khususnya seorang kepala kelurahan yang bersentuhan langsung dengan masyarakat pada dasarnya memang harus dapat membaca, mengetahui dan memahami situasi dan kondisi masyarakat di kelurahannya, sehingga dengan demikian lebih memudahkan untuk mengambil suatu langkah dan cara dalam melakukan sesuatu kemudian dapat menciptakan suatu kebijakan yang tidak merugikan seseorang atau kelompok-kelompok tertentu.

Kebijakan atau keputusan seorang pemimpin khususnya kepala kelurahan belum pasti semua masyarakat dapat menerimanya dan melaksanakannya, makanya diperlukan suatu kepemimpinan yang baik yagng dapat membuat masyarakat mau menerima kebijakan tersebut. Kepemimpinan Lurah Cabenge dalam menggerakkan masyarakat dalam kegiatan pembangunan dengan cara mengajak, membujuk dan meyakinkan masyarakat sudah sering dilakukan khususnya pada saat seseorang meminta pelayanan di Kantor Lurah Cabenge. Hal ini berdasarkan dari pengamatan penulis pada saat bapak Lurah Cabenge berkesempatan berdialog dengan masyarakat, beliau pasti akan berbicara dengan kata-kata yang sopan kemudian membujuknya untuk berpartisipasi terhadap pembangunan disekitar lingkungan masyarakat tersebut.

Aktivitas Lurah Cabenge dengan cara berdialog langsung dengan masyarakat awam dapat lebih menggugah hatinya dan menyentuh perasaannya karena merasa dihargai oleh seorang pemimpin sehingga dengan cepat juga mudah dipengaruhi untuk berpartisipasi terhadap pembangunan. Hal ini sesuai dengan hasil kesimpulan wawancara yang dilakukan oleh penulis dengan responden yang diperoleh informasi bahwa beberapa orang masyarakat Kelurahan Cabenge mau berpartisipasi dalam pelaksanaan pembangunan karena cara-cara Lurah Cabenge sering mengajak dan meyakinkan warganya untuk berpartisipasi dalam pembangunan.

Berdasakan uraian di atas maka dapat disimpulkan bahwa kepemimpinan Lurah Cabenge dengan cara membujuk dan mengajak masyarakat sudah dapat menggerakkan masyarakat untuk berpartisipasi terhadap pembangunan.

\section{b. Aktivitas atau Kegiatan Lurah Dalam Memberikan Motivasi}

Motivasi merupakan salah satu faktor yang sangat menentukan kebehasilan seseorang dalam melakukan sesuatu, tanpa adanya motivasi yang dimiliki, maka sudah dapat dipastikan pekerjaan yang dilakukan tidak akan berhasil sesuai dengan yang diharapkan atau dicita-citakan sebelumnya. Pemberian motivasi kepeda seseorang atau sekelompok orang agar mau dan mampu melakukan sesuatu yang diharapkan pada dasarnya merupakan salah satu dari sifat seorang pemimpin. Seorang pemimpin harus memiliki cara-cara tersendiri sehingga para bawahannya atau orang yang dipimpinnya dapat melakukan hal-hal yang diinginkannya. Salah satu yang biasa dilakukan oleh sebagian besar pemimpin baik pada instansi pemerintah maupun swasta yaitu dengan memberikan motivasi dalam bentuk reward atau penghargaan kepada bawahannya yang berprestasi.

Pemberian motivasi kepada masyarakat dalam menggerakkannya untuk ikut aktif berpartisipasi dalam pembengunan juga salah satu faktor yang menentukan. Oleh sebab itu, Kepala Kelurahan sebagai pemimpin yang dekat dan bersentuhan langsung dengan masyarakat harus memiliki cara-cara tertentu dalam memberikan motivasi kepada masyarakat yang disesuaikan dengan tingkat kebutuhan masyarakat dan kemampuan dari seorang pemimpin dalam hal ini pemerintah kelurahan.

Dalam menggerakkan masyarakat untuk aktif berpartisipasi dalam pembangunan dengan carapemberian motivasi kepada masyarakat telah lama dilakukan oleh bapak Lurah Cabenge, berdasarkan wawancara dengan bapak Lurah Cabenge pada tanggal 27 Maret 2014 diperoleh informasi bahwa beliau sejak pertama kali menjabat sebagai Lurah Cabenge telah seringkali memberikan motivasi kepada masyarakat. Lebih lanjut beliau mengatakan bahwa pemberian motivasi sematamata hanya untuk merangsang masyarakat untuk turut serta berpartisipasi dalam kegiatan pembangunan di Kelurahan Cabenge dan bukan ada maksud apa-apa.

Pemberian motivasi oleh Lurah Cabenge biasanya dilakukan dalam berbagai bentuk, tetapi yang sering beliau berikan yaitu berupa bebas biaya administrasi apapun di Kantor Lurah Cabenge kepada masyarakat yang benarbenar aktif berpartisipasi terhadap pembangunan. Lebih lanjut dia mengatakan bahwa : "pemberian motivasi semacam ini merupakan bentuk terima kasih dan penghargaan kita kepada masyarakat yang berpartisipasi dalam pembangunan. Pemberian motivasi tersebut merupakan salah satu kebijakan saya sebagai seorang lurah dalam mendorong dan merangsang masyarakat untuk berpartisipasi dalam pembangunan yang ada di Kelurahan Cabenge (wawancara pada tanggal 27 Maret 2014)

Pemberian motivasi berupa pembebasan biaya administrasi di Kantor Kelurahan Cabenge dibenarkan oleh salah satu tokoh masyarakat berdasarkan wawancara yang dilakukan penulis di Kelurahan Cabenge yang mengatakan bahwa "di Kantor Lurah Cabenge tidak dipungut biaya apapun dalam mengurus sesuatu asalkan orang tersebut aktif berpartisipasi dalam kegiatan pembangunan". (Wawancara dengan Bapak A. Ulis pada tanggal 28 Maret 2014)

Untuk mengetahui apakah masyarakat tersebut aktif atau tidak berpartisipasi terhadap pembangunan, mereka harus menunjukkan pengantar Kepada Lingkungan masing-masing yang berisi bahwa orang tersebut benar aktif dalam proses pembangunan di Kelurahan Cabenge yang selanjutnya di proses di Kantor Lurah Cabenge.

Hal ini juga dibenarkan oleh salah seorang Kepala Lingkungan sesuai dengan wawancara yang dilakukan oleh penulis yang mengatakan bahwa "Saya sering memberikan pangantar bebas biaya apapun kepada warga saya yang benar-benar aktif dalam kegiatan pembangunan di wilayah saya, karena saya tahu persis siapa warga saya yang aktif atau tidak". (wawancara dengan Bapak A. Mappiasse pada tanggal 28 Maret 2014). 
Berdasarkan pengamatan yang dilakukan oleh penulis di Kantor Lurah Cabenge dapat dilihat bahwa masyarakat yang benar-benar aktif berpartisipasi dalam pembangunan dibebaskan biaya administrasi di Kantor Lurah. Masyarakat tersebut hanya memperlihatkan surat pengantar dari Kepala Lingkungan kemudian staf kelurahan memproses sesuai dengan permintaan pelayanan masyarakat tersebut tanpa di pungut biaya apapun.

Pemberian motivasi yang dilakukan oleh bapak Lurah Cabenge berupa pembebasan biaya administrasi kepada masyarakat yang benar-benar aktif dalam kegiatan pembangunan mendapat respon yang sangat positif dari sebagian besar masyarakat Kelurahan Cabenge, berdasarkan wawancara kepada salah seorang kepala keluarga yang mengatakan bahwa : "Kami sangat senang dan berterima kasih kepada bapak Lurah Cabenge yang telah menghargai jerih payah kami dengan membebaskan biaya administrasi di Kantor Lurah walaupun tidak sebanding dengan apa yang kami lakukan dalam pembangunan tetapi bapak Lurah telah berusaha menghargainya" (wawancara dengan Bapak Ari pada tanggal 1 April 2014)

Pembebasan biaya administrasi yang merupakan salah satu cara pemberian motivasi untuk aktif berpartisipasi dalam pembangunan kepada masyarakat, oleh sebagian masyarakat bukan sekedar dianggap sebagai rangsangan semata tetapi dianggap sebagai penghematan biaya pengeluaran dalam mengurus sesuatu di Kantor Lurah karena menurut salah satu Kepala Lingkungan yang diwawancarai oleh penulis mengatakan bahwa "beberapa masyarakat di Kelurahan Cabenge termotivasi karena adanya pembebasan biaya administrasi di Kantor Lurah" (wawancara dengan Bapak Arsyad pada tanggal 1 April 2014). Kebanyakan masyarakat tersebut berasal dari mereka yang mempunyai penghasilan yang rendah sehingga menurut mereka dengan tanpa menyumbangkan biaya atau yang lain sebagainya mereka sudah dapat menghemat biaya kepengurusan di Kantor Lurah Cabenge.

Pemberian motivasi sangat mendorong masyarakat untuk berpartisipasi dalam pembangunan, bukan hanya kaum laki-lakinya saja yang turut serta berpartisipasi tetapi kaum perempuannya pun atau ibu-ibu yang tidak mau ketinggalan. Hal ini berdasarkan wawancara dengan salah seorang tokoh masyarakat yang mengatakan bahwa "Ibu-ibu juga memiliki motivasi yang tinggi untuk ikut berpartisipasi dalam kegiatan pembangunan ini dengan cara menyiapkan konsumsi bagi warga masyarakat yang bekerja di sekitar tempat tinggalnya". (wawancara dengan Bapak Agus pada tanggal 2 April 2014). Lebih lanjut beliau mengatakan bahwa biasanya ibu-ibu tersebut bergiliran membawakan komsumsi yang dibawa dari rumahnya masing-masing. Komsumsi tersebut berupa makan pagi, makan siang atau bahkan makan malam apabila kerjanya sampai malam. Selain itu ibu-ibu yang lain menyiapkan air kopi, air teh dan lain-lain. Maupun kue-kue atau makan makanan ringan.

Dan hasil pengamatan penulis yang dilakukan di salah satu lokasi pembangunan nampak adanya ibu-ibu yang membawa komsumsi pada saat jamjam istirahat dengan membawa komsumsi. Mereka membawa makanan dan kopi atau teh untuk kaum laki-laki yang sedang bekerja. Berbagai macam komsumsi yang disiapkan ibu-ibu tersebut mulai dari makan siang sampai kopi atau teh snacknya juga tidak ketinggalan.

Dari uraian diatas nampak bahwa pemberian motivasi dari bapak Lurah Cabenge mendorong masyarakat untuk berpartisipasi dalam pembangunan bukan hanya dari kaum laki-laki saja tetapi melibatkan kaum perempuan yang turut serta mengambil bagian berpartisipasi dalam menyiapkan komsumsi para pekerja.

Tetapi berbeda dengan hasil wawancara seorang Kepala Keluarga yang menurut penilaiannya mengatakan bahwa "pemberian motivasi seperti itu menyebabkan rasa ketidakadilan kepada seluruh warga masyarakat Kelurahan Cabenge" (Hasil wawancara dengan Bapak Anto pada tanggal 2 April 2014). Lebih lanjut dia menilai bahwa tidak semua orang dapat memberikan biayanya, tidak semua orang sempat memberikan tenaganya karena sesuatu dan lain sehingga orang tersebut sudah tentu tidak aktif dalam kegiatan pembangunan sehingga dia tetap membayar setiap kali mengurus sesuatu di Kantor Lurah.

Rasa ketidakadilan yang dinilai beberapa warga masyarakat di Kelurahan Cabenge terkait dengan pemberian motivasi oleh bapak Lurah Cabenge dalam menggerakkan partisipasi masyarakat dalam kegiatan pembangunan memang juga bisa dimaklumi. Hal ini disebabkan karena setiap masyarakat memiliki aktivitas dan kesibukan masing-masing yang berbeda-beda dengan satu dan yang lainnya khususnya perbedaan dalam mata pencaharian. Apalagi wilayah Kelurahan Cabenge yang mempunyai wilayah perkebunan dan persawahan yang cukup luas menyebabkan sebagian besar penduduknya bermata pencaharian sebagai petani/pekebun.

Menanggapi hal tersebut bapak Lurah Cabenge mengatakan bahwa "Adil itu bukan harus sama rata tetapi kebersamaan dalam berpartisipasi terhadap pembangunan yang harus dimiliki oleh setiap masyarakat serta kebersamaan dalam menerima hasil pembangunan tersebut". (Hasil wawancara pada tanggal 3 April 2014). Menurutnya kalau memang ada warga masyarakat yang tidak sempat memberikan tenaga atau memberikan biaya dalam pembangunan mereka dapat berpartisipasi dalam bentuk yang lain misalnya seorang petani/pekebun yang setiap harinya waktu dan tenaganya dihabiskan di kebun dan sawah, dia bisa saja menyumbangkan sebagian hasil kebunnya sebagai komsumsi yang akan diberikan kepada masyarakat yang lain yang bekerja. Lebih lanjut bapak Lurah Cabenge mengatakan bahwa dia tidak mempersulit setiap warganya untuk ikut berpartisipasi dalam kegiatan pembangunan sepanjang meraka mau dan ikhlas kita pasti mencarikan solusi yang terbaik bagi mereka.

Pemberian motivasi dalam rangka menggerakkan masyarakat untuk ikut serta berpartisipasi dalam pembangunan yang dilakukan oleh bapak Lurah Cabenge sudah merangsang warga masyarakat untuk berpartisipasi dalam kegiatan tersebut. Hal ini didasarkan pada wawancara penulis dengan beberapa responden yang hampir keseluruhan merespon positif pemberian motivasi tersebut.

Berdasarkan hasil pengamatan penulis dapat dilihat dari banyaknya masyarakat yang membawa surat pengantar bebas biaya administrasi dari Kepala Lingkungan membuktikan bahwa masyarakat mempunyai motivasi 
yang tinggi dalam berpartisipasi terhadap pembangunan di Kelurahan Cabenge.

Kepemimpinan Lurah Cabenge dengan cara memberikan motivasi kepada warga masyarakatnya yang aktif berpartisipasi dalam pembangunan merupakan salah satu gaya yang harus dimiliki oleh seorang pemimpin dalam mempengaruhi bawahannya atau yang dipimpinnya. Gaya motivasi ini sesuai dengan pendapat pemudji dimana pemimpin dalam menggerakkan orang-orang memberikan hadiah-hadiah atau reward maupun yang bersifat hukuman (penalties) atau bersifat negative. Lebih lanjut lagi pamudji berpendapat bahwa bagi setiap pemimpin pemerintahan di Indonesia haruslah memahami dua fungsi penting kepemimpinan pemerintah yaitu fungsi pengambilan keputusan dan fungsi motivasi. Fungsi kepemimpinan yang kedua yakni memotivasi berarti seorang pemimpin harus mampu memberikan motivasi kepada bawahannya sehingga mereka lebih bersemangat dalam menyelesaikan pekerjaannya dengan hasil yang baik.

Seseorang pemimpin khususnya pemimpin kelurahan yang juga bertindak sebagai kepala pemerintahan pada tingkat kelurahan serta melaksanakan fungsi pembangunan pada dasarnya harus mampu dan memiliki manajemen kepemimpinan yang baik sehingga dalam mengatur suatu masyarakat yang homogen tidak mengalami kesulitan serta dapat dengan cepat mencari solusi yang terbaik apabila ada masalah yang terjadi tanpa mengorbankan apapun dan siapapun.

Berdasarkan uraian diatas dapat disimpulkan bahwa kepemimpinan lurah dengan cara memberikan motivasi berupa pembebasan biaya administrasi sangat menggerakkan masyarakat dalam berpartisipasi terhadap pembangunan di Kelurahan Cabenge.

\section{Peranan Lurah Secara Akomodatif dalam Meningkatkan Partisipasi Masyarakat terhadap Pembangunan}

Peranan Lurah secara akomodatif adalah aktivitas lurah dalam menggerakakan masyarakat secara akomodatif dalam hal menampung aspirasi masyarakat maupun memberikan informasi dalam pembangunan di wilayahnya. Aktivitas lurah ini pada dasarnya sangat mempengaruhi partisipasi masyarakat, karena dengan adanya informasi yang jelas akan mendorong warga masyarakat dalam berpartisipasi terhadap pembangunan demikian juga dengan aktivitas lurah dalam menampung aspirasi masyarakat sebagai salah satu wujud adanya masukan atau ide-ide warga masyarakat tersebut sebagai pemanfaat hasil-hasil pembangunan tersebut.

\section{Aktivitas atau Kegiatan Lurah dalam Memberikan Informasi}

Keberhasilan kepemimpinan seseorang bukan hanya dilihat dari mampu tidaknya mengatur dan mengendalikan bawahannya tetapi lebih mengutamakan pada terjalinnya komunikasi yang baik antara atasan dengan bawahan, antara sang pemimpin dan yang di pimpin sehingga akan mewujudkan kepemimpinan yang demokratis
Pemberian informasi yang jelas dari seorang lurah kepada masyarakat merupakan salah satu factor pendukung dalam rangka menggerakkan masyarakat untuk aktif berpartisipasi dalam pembangunan yang dilaksanakan. Tanpa adanya informasi sebagai langkah awal pelaksanaan pembangunan masyarakat tidak mungkin mengetahui adanya pelaksanaan pembangunan di sekitar tempat tinggalnya, sehingga pemberian informasi yang jelas dan terus - menerus merupakan hal penting di lakukan oleh seorang dalam menggerakkan partisipasi masyarakat

Berdasarkan hasil wawancara dengan bapak Lurah Cabenge 3 April 2014, diperoleh informasi bahwa selain untuk menciptakan komunikasi yang baik antara pemerintah kelurahan dengan masyarakat, Pemberian informasi yang jelas juga dapat merangsang masyarakat untuk aktif berpartisipasi dalam pembangunan. Penyampaian program-program pembangunan baik yang telah dilaksanakan maupun yang baru akan dilaksanakan di informasi secara lengkap kepada masyarakat baik itu dari segi waktu pelaksanaannya, besarnya bantuan dari pemerintah serta di sampaikan pula swadaya masyarakat yang harus di tanggung bersama oleh masyarakat baik itu swadaya berupa dana, swadaya berupa barang ataupun swadaya berupa pikiran atau ide-ide dalam pembangunan tersebut.

Lebih lanjut bapak Lurah Cabenge menjelaskan bahwa pemberian atau penyampaian informasi beliau sering lakukan setiap ada kesempatan berdialog dengan masyarakat baik itu acara formal maupun tidak formal. Pada acara formal pemberian informasi menyangkut masalah pembangunan biasanya dilakukan dalam rapat - rapat tertentu khususnya pada rapat pelaksanaan musyawarah Rencana Pembangunan atau Musrembang yang dilaksanakan setiap tahunnya sebagai langkah awal perencanaan pelaksanaan pembangunan. Menurut beliau pelaksanaan Musrembang tingkat Kelurahan Cabenge Tahun 2013 telah selesai dilaksanakan, pada kesempatan tersebut bapak Lurah Cabenge menyampaikan informasi menyangkut beberapa rencana pembangunan yang dilaksanakan di wilayah Kelurahan Cabenge pada tahun ini serta memberikan informasi terkait masalah hasil Musrembang tahun lalu yang belum sempat terlaksana pembangunannya sampai sekarang.

Penyampaian informasi tersebut dibenarkan oleh salah seorang tokoh pemuda yang sempat hadir pada acara Musrembang tersebut, mengatakan bahwa : "pada acara Musrembang beberapa bulan yang lalu bapak Lurah Cabenge menyampaikan beberapa informasi menyangkut rencana pelaksanaan pembangunan yang ada di Kelurahan Cabenge secara lengkap dan jelas sehingga semua yang hadir dapat lebih mengetahui." (Wawancara dengan Bapak Hedar pada tanggal 4 April 2014)

Hal tersebut di dukung oleh pengumpulan data oleh penulis berupa dokumentasi pelaksanaan Musrembang yang telah dilaksanakan beberapa bulan yang lalu.

Selain itu hasil wawancara dengan salah satu tokoh agama yang mengatakan bahwa : "bukan hanya acara rapat musrembang bapak Lurah Cabenge 
menyampaikan informasi tersebut, tetapi rapat-rapat formal yang lain pun bapak Lurah Cabenge biasa menyampaikannya pada akhir pidatonya baik itu pada kegiatan keagamaan, kemasyarakatan dan lainlain" (Wawancara dengan Bapak M. Siri pada tanggal 7 April 2014)

Selain pada acara formal tersebut bapak Lurah Cabenge menyampaikan informasi yang menyangkut masalah pembangunan juga dalam berbagai acara non formal atau secara kekeluargaan yang dilakukan misalnya menerima undangan dari warga maupun sekedar mengunjunginya untuk mengetahui keadaan lingkungan wilayahnya. Dalam setiap kesempatan tersebut bapak Lurah Cabenge selalu memberikan informasi mengenai pelaksanaan pembangunan ataupun hal-hal lain yang menyangkut kepentingan pemerintah kelurahan dan warga masyarakat.

Hal ini juga sesuai dengan pengamatan yang dilakukan penulis terhadap aktivitas Lurah Cabenge yang menyampaikan informasi pada acara syukuran oleh salah satu warga masyarakat pada tanggal 17 April 2014. Pada kesempatan itu bapak Lurah menyampaikan informasi mengenai pembangunan yang dilaksanakan di Kelurahan Cabenge, bapak lurah Cabenge juga meminta kesediaan masyarakat untuk bersama-sama berpartisipasi dalam pembangunan tersebut.

Penyampaian informasi mengenai masalah pembangunan yang dilaksanakan di Kelurahan Cabenge juga di umumkan di papan pengumuman khusus informasi mengenai pembangunan, mempunyai papan tersendiri di Kantor Lurah Cabenge hal ini bertujuan untuk memudahkan masyarakat mengetahui apabila datang di Kantor Lurah untuk meminta pelayanan.

Dengan adanya papan informasi yang ada di Kelurahan Cabenge penyampaian informasi akan lebih cepat diketahui oleh warga masyarakat. Masyarakat yang datang di Kantor Lurah Cabenge dapat langsung melihat pelaksanaan pembangunan di Kelurahan Cabenge.

Keaktifan bapakLurah Cabenge dalam memberikan informasi kepada masyarakat mengenai masalah pembangunan di Kelurahan Cabenge oleh sebagaian besar masyarakat dinilai sudah berhasil menggerakkan masyarakat untuk berpartisipasi terhadap pembangunan hal ini didasarkan oleh wawancara yang dilakukan oleh penulis dengan salah seorang tokoh masyarakat yang mengatakan "informasi bagi kami sangat penting sebelum kami berpartisipasi terhadap pembangunan di kelurahan ini, terutama dari bapak lurah sebagai orang yang di tuakan karena informasinya tidak diragukan lagi" (Wawancara dengan Bapak Iskandar Melle pada 8 April 2014).

Informasi dari oknum atau seseorang yang bukan berasal dari bapak Lurah masih sangat di ragukan kebenarannya sehingga masyarakat akan lebih percaya dan yakin untuk berpartisipasi apabila bapak Lurah Cabenge sendiri yang menyampaikannya. Selain itu wawancara kepada salah seorang kepala keluarga yang menyatakan bahwa : "Sebenarnya kami hanya menunggu informasi dari bapak Lurah terlebih dahulu sebelum kami mempersiapkan segalanya untuk berpartisipasi terhadap pembangunan tersebut, karena kami yakin informasi dari bapak Lurah itu tidak mengada-ada di bandingkan dengan informasi dari yang lain". (Wawancara dengan Bapak Ardi pada 8 April 2014)

Dari uraian diatas nampak bahwa keinginan masyarakat untuk berpartisipasi dalam pembangunan di tentukan oleh pemberian informasi yang jelas dari bapak Lurah Cabenge. Karena pada dasarnya sudah ingin berpartisipasi tetapi hanya menunggu informasi yang jelas dari seseorang yang bisa dan dapat di percaya dalam hal ini bapak Lurah Cabenge. Pemberian informasi yang jelas serta dilaksanakan lebih awal akan memberikan kesempatan bagi warga masyarakat untuk mempersiapkan diri untuk berpartisipasi dalam pembangunan, baik itu dalam bentuk ide atau aspirasi, bentuk material atau dan bentuk tenaga. Persiapan sangat penting bagi warga masyarakat mengingat kesibukan aktivitas warga masyarakat Kelurahan Cabenge dalam kehidupan sehari-hari.

Namun demikian, berdasarkan wawancara bapak Lurah Cabenge tanggal 9 April 2014, mengakui bahwa frekuensi kunjungan dalam memberikan informasi tidak dapat di laksanakan secara merata pada berbagai tempat di wilayah karjanya karena kesibukannya didalam membenahi administrasi kelurahan, melaksanakan berbagai perintah atau intruksi dari pemerintah tingkat atas sehingga tidak tersedianya waktu untuk mengunjungi warga masyarakat. Walaupun sebenarnya keberadaan lurah sebagai pemimpin dalam suatu masyarakat dan yang paling bersentuhan langsung dengan masyarakat seharusnya frekuensi kebersamaan dengan masyarakat haruslah seimbang bahkan lebih banyak bersama masyarakat sehingga keakraban dan tali silaturahmi antara seorang lurah dengan masyarakat dapat terjadi setiap waktu dan setiap saat.

Berdasarkan pengamatan penulis juga diketahui bahwa aktivitas Lurah Cabenge dalam melaksanakan tugasnya setiap hari memiliki banyak kesibukan karena selain menyelenggarakan tugas pemerintah, bapak Lurah Cabenge juga pembangunan dan kemasyarakatan, sehingga waktu bapak Lurah Cabenge setiap harinya kebanyakan di kantor dibanding di masyarakat.

Berdasarkan uraian tersebut diatas penulis menyimpulkan bahwa keaktifan Lurah Cabenge dalam memberikan informasi kepada masyarakat baik itu pada rapat formal maupun pertemuan dengan warga masyarakat serta adanya papan informasi pembangunan mengenai masalah pembangunan sudah cenderung mendorong masyarakat untuk bergerakdan berpartisipasi dalam pembangunan.

\section{Aktivitas Atau Kegitan Lurah Dalam Menerima Aspirasi Masyarakat}

Seorang pemimpin masyarakat pada dasarnya sangat jauh berbeda dengan pemimpin sebuah perusahaan swasta dimana dalam pengambilan sebuah kebijakan berasal dari pucuk pimpinan atau sang direktur tetapi kepemimpinan dalam masyarakat haruslah lebih dahulu mengutamakan kepentingan masyarakat dalam mengambil suatu kebijakan, 
Oleh sebab itu seorang pemimpin masyarakat atau dalam hal ini Kepala Kelurahan terlebih dahulu mengutamakan aspirasi masyarakat untuk di jadikan pedoman dalam pengambilan sebuah kebijakan atau keputusan.

Kepala Kelurahan Cabenge dalam setiap aktivitasnya selalu mengutamakan atau mendahulukan kepentingan masyarakat dengan cara menampung aspirasi atau pendapat masyarakat terlebih dahulu termasuk dalam hal pelaksanaan pembangunan di Kelurahan Cabenge. Hal tersebut sesuai dengan informasi yang di dapat dari bapak Lurah Cabenge berdasarkan wawancara yang dilakukan penulis tanggal 10 Maret 2014 yang mengatakan bahwa "aspirasi atau pendapat masyarakat khususnya dalam bidang pembangunan sangatlah membantu dalam proses pelaksanan pembangunan khususnya pada saat perencanaan pembangunan tersebut". Lebih lanjut dia mengatakan bahwa memang sangat disayangkan sedikitnya antusius atau semangat dalam memberikan masukan atau informasi terkait pelaksanaan pembangunan yang akan dilakukan di Kelurahan Cabenge, dalam acara Musrembang tahun 2014 sedikitnya hanya 7 (Tujuh) orang memberikan masukan terkait pelaksanaan pembangunan yang akan dilakukan di Kelurahan Cabenge sedangkan jumlah peserta Musrembang yang hadir sebanyak 53 orang, hal ini membuktikan bahwa antusius masyarakat dalam menghadiri acara Musrembang sudah cukup baik.

Sedangkan antusius peserta rapat Musrembang tingkat kelurahan Cabenge dalam memberikan aspirasi atau masukan bahwa antusias warga dalam memberikan aspirasinya masih cukup rendah, dari 53 orang peserta musrembang yang hadir hanya 7 orang saja yang memberikan usulan atau aspirasinya. Keikut sertaan masyarakat dalam pelaksanaan Musrembang sangatlah diperlukan dalam pelaksanaan pembangunan khususnya dari segi perencanaannya. Tanpa adanya aspirasi dari masyarakat pemerintah atau dalam hal ini Kepala Kelurahan Cabenge tidak dapat membuat usulan perencanaan pembangunan yang akan dilaksanakan di Kelurahan Cabenge. Karena pada dasarnya masyarakatlah yang menjadi subjek sekaligus objek dari pembangunan tersebut.

Hal ini juga di benarkan oleh salah seorang Kepala Lingkungan yang sempat hadir dalam acara tersebut mengatakan bahwa "sedikitnya aspirasi atau usulan dalam Musrembang tersebut di sebabkan karena masih adanya masyarakat yang berpikir kalau ide/usulan mereka biasanya tidak terealisasi atau harus menunggu bertahuntahun". (Wawancara dengan Bapak A.Mappiasse pada tanggal 11 April 2014) Hasil pelaksanaan Musrembang tersebut tidak selalu akan langsung mendapat persetujuan dari pemerintah baik itu daerah tetapi Musrembang tingkat kelurahan merupakan langkah awal bagi pelaksanaan Musrembang tingkat kecamatan dan kabupaten jadi masih memerlukan suatu perjuangan dalam proses selanjutnya sesuai dengan prosedur. Menurut bapak Lurah Cabenge yang mengatakan bahwa: 'tidak semua hasil Musrembang tingkat kelurahan ini akan langsung di berikan persetujuan tetapi masih ada langkah panjang yang akan kita tempuh, semua hasil Musrembang pada tahun ini tetap akan saya jadikan prioritas utama khususnya aspirasi masyarakat yang sudah diusulkan beberapa kali dalam pelaksanaan musrembag sebelumnya. Pelaksanaan pembangunan tahun ini yang sedang berlangsung di Kelurahan Cabenge salah satunya merupakan hasil Musrembang sebagai bagian dari aspirasi masyarakat". (Wawancara pada tanggal 21 Januari 2014)

Berdasarkan pengamatan penulis dilapangan bahwa kondisi jalan Ranjau memang sangat memperhatikan, padahal aktivitas oleh beberapa warga masyarakat setiap harinya sangat bergantung pada jalan tersebut. Sehingga pengusulan untuk segera memperbaiki jalan tersebut sudah wajar untuk dilakukan.

Penyampaian aspirasi masyarakat khususnya dalam pelaksanaan perencanaan pembangunan pada dasarnya telah diatur dalam Undang-undang nomor 25 tahun 2004 tentang Perencanaan Pembangunan Nasional, sehingga secara formal aspirasi masyarakat menyangkut perencanaan pembangunan ataupun pelaksanannya sudah tepat dilaksanakan pada acara tersebut.

Namun tingkat kehadiran dalam rapat Musrembang dan aspirasi masyarakat masih rendah, hal ini terjadi karena belum semua masyarakat dapat hadir dalam acara tersebut namun karena faktor kesibukan dari aktivitas masyarakat beberapa diantaranya belum dapat hadir, hal ini dapat kita lihat dari wawancara yang dilakukan oleh penulis yang mengatakan bahwa : "saya sudah dua tahun terakhir ini tidak pernah hadir dalam acara tersebut walaupun pihak kelurahan telah memberikan undangannya tetapi karena pelaksanaannya selalu sama dengan tugas pokok saya makanya saya tidak sempat hadir padahal ada hal yang ingin saya usulkan dalam Musrembang tersebut yang menurut saya sangat penting”. (Wawancara dengan Bapak H. Pammu pada tanggal 10 Maret 2014)

Uraiandiatasmenunjukkanadanyakeinginanmasyarakat yang sangat tinggi untuk menghadiri acara Musrembang tersebut, tetapi karena waktu dan kesempatannya yang tidak memungkinkan untuk mengikutin acara tersebut, hal ini terjadi karena salah satunya adalah profesi seseorang yang memang sibuk.

Hal ini juga dibenarkan bapak Lurah Cabenge dari hasil wawancara dia mengatakan bahwa "memang tidak semua yang diundang itu dapat hadir karena mungkin dari kesibukan atau aktifitas seseorang sehingga orang tersebut tidak sempat hadir". (wawancara pada 14 Maret 2014), untuk mencocokkan jadwal setiap orang yang akan diundang dengan pelaksanaan Musrembang sangatlah susah karena terlalu banyaknya peserta yang diundang makanya kami mengundang lebih dari satu orang yang dinilai dapat mewakili setiap kelompoknya sehingga apabila satu orang tidak sempat maka masih ada dari kelompoknya yang mewakili aspirasinya. Jadwal pelaksanaan Musrembang tersebut biasanya sudah ditentukan sebelumnya oleh pihak Kecamatan sehingga pihak Kelurahan hanya dapat menyesuaikan dengan jadwal yang sudah ditetapkan.

Kepemimpinan Lurah Cabenge yang selalu menampung aspirasi masyarakat membuktikan bahwa Lurah Cabenge peka terhadap saran-saran 
dari masyarakat yang dipimpinya, hal ini sesuai dengan salah satu metode kepemimpinan yang dikemukan oleh orddway tead dalam kartini yang menjelaskan bahwa sifat pemimpin itu harus luwes dan terbuka, dan peka pada saran-saran eksternal, serta menghargai pendapat-pendapat orang lain untuk mengkombinasikannya dengan ide-ide sendiri.

Penyampaian aspirasi masyarakat di Kelurahan Cabenge khususnya dalam pembangunan dapat dikatakan masih rendah, hal ini dapat kita lihat dari antusius warga masyarakatnya yang mengikuti pelaksanaan Musrembang atau warga masyarakat yang memberikan usulan atau ide-ide pada acara tersebut di Kantor Lurah Cabenge beberapa waktu yang lalu. Walaupun aktifitas Lurah Cabenge dalam hal menampung aspirasi atau masukan dari masyarakat menyangkut masalah pembangunan telah dilaksanakan dengan baik dan penuh tanggung jawab namun tingkat kesadaran masyarakat yang belum mengerti betul akan pentingnya ide atau usulan dari masyarakat dalam hal pelaksanaan pembangunan.

\section{Peranan Lurah Secara Dinamis Antisipasi dalam Meningkatkan Partisipasi Masyarakat terhadap Pembangunan}

Peranan Lurah secara dinamis antisipastif dalam meningkatkan partisipasi masyarakat terhadap pembangunan adalah kegiatan lurah dalam menggerakkan masyarakat berupa pemeliharaan hasil pembangunan dan pegawasan hasil pembangunan sehingga dapat mengantisipasi hal-hal yang tidak diinginkan sehingga pemakaian atau pemanfaatan hasil pembangunan tersebut dapat berlangsung lama. Aktivitas tersebut sangat penting untuk melibatkan masyarakat karena selain keberadaan masyarakat yang berada dekat dengan hasil pembangunan, masyarakat juga merupakan pemanfaat hasil dari pembangunan tersebut.

\section{Avitas Atau Kegiatan Lurah Dalam Memelihara Hasil Pembangunan}

Partisipasi masyarakat dalam pembangunan bukan hanya sekedar memberikan masukan pada saat proses pembangunan akan dimulai atau terlibat langsung dalam proses pembangunan sedang berlangsung, tetapi partisipasi masyarakat juga di haruskan terlibat pada saat pembangunan itu telah selesai, yakni pada pemeliharaan hasil-hasil pembangunan tersebut.

Sebagai seorang pemimpin dalam suatumasyarakat seorang lurah dalam menggerakkan masyarakatnya untuk berpartisipasi terhadap pemeliharaan hasil-hasil pembangunan didaerahnya memang sangat memerlukan suatu teknik kepemimpinan tersendiri, karena pada umumnya masyarakat hanya taunya memakai dan mempergunakan hasil-hasil pembangunan tersebut tanpa mau bertanggung jawab dalam pemeliharaannya,

Lurah Cabenge dalam menggerakkan masyarakat untuk bertanggung jawab dalam pemeliharaan hasilhasil yang ada di kelurahan telah melakukan berbagai upaya. Hal ini sesuai dengan hasil wawancara yang dilakukan oleh penulis kepada bapak Lurah Cabenge pada 15 April 2014 di peroleh informasi bahwa di Kelurahan Cabenge akan di bentuk suatu lembanga atau kelompok masyarakat yang bertujuan untuk memelihara hasil-hasil pembangunan disekitarnya atau yang disebut KPPM atau (Kelompok Pemeliharaan Prasarana Masyarakat), Menurut bapak Lurah Cabenge kelompok tersebut terbentuk karena melihat selama ini masyarakat saling mengharapkan satu dengan yang lainnya untuk bertanggung jawab dalam pemeliharaan tersebut sehingga beliau berinisiatif untuk membentuk KPPM (Kelompok Pemeliharaan Prasarana Masyarakat). Kelompok tersebut nantinya akan beranggotakan 5 sampai 10 orang tergantung besar fasilitas tersebut yang akan dipelihara bersama-sama dengan penuh rasa tanggung jawab.

Pemeliharaan hasil-hasil pembangunan memang sebaiknya masyarakatlah yang paling berperan penting karena selain fasilitas-fasilitas tersebut mereka yang paling banyak menggunakannya, masyarakatlah juga pada umumnya lebih banyak tahu akan kondisi fasilitas tersebut, sehingga dengan cepat berfikir dan bertindak dalam mencarikan solusi yang terbaik apabila dalam suatu fasilitas kemasyarakatan mengalami kerusakan atau yang lain. Berdasarkan wawancara penulis dengan salah satu tokoh agama yang mengatakan "Kami biasanya akan mengadakan rapat apabila ada suatu fasilitas yang kita perbaiki kemudian kita bersama-sama menyepakati besarnya biaya, waktu pelaksanaan dan lain-lain sehingga fasilitas tersebut dapat terpelihara dengan baik" (Wawancara dengan Bapak M. Siri pada tanggal 15 April 2014)

Terbentuknya lembaga tersebut selain dapat menunjang pemakaian fasilitas umum dalam waktu yang lama, kelompok tersebut juga berfungsi sebagai sarana untuk menjalin kerjasama antar sesama anggotanya serta untuk menumbuhkan rasa tanggung jawab bersama kepada fasilitas atau sarana umum yang diberikan kepadanya. Salah satu tokoh masyarakat mengatakan "perbaikan jembatan umum di jalan Cabenge merupakan hasil kerja kami anggota KPPM yang berjumlah Sembilan orang, Dana yang kami butuhkan dalam memperbaiki jembatan tersebut terbilang cukup besar tetapi karena kami bersama-sama bartanggung jawab makanya tidak ada masalah sehingga sampai sekarang dapat dinikmati lagi" (Wawancara dengan Bapak Syamsurijal pada tanggal 16 April 2014)

Dari uraian diatas nampak antusius warga masyarakat dalam memelihara hasil pembangunan cukup tinggi, hal ini di karenakan adanya kelompok yang sudah terbentuk sehingga anggota kelompok tersebut telah memiliki tanggung jawab masing-masing, selain itu kerjasama yang baik antar sesama anggota kelompok dalam menyelesaikan suatu masalah sangat terjalin dengan baik dan akrab.

Namun belum semua fasilitas atau sarana dan prasarana umum yang belum terpelihara dengan baik, berdasarkan pengamatan penulis dilapangan nampak bahwa fasilitas atau prasarana umum dibeberapa tempat di Kelurahan Cabenge sudah tidak terpelihara dengan baik sehingga kondisinya memprihatinkan, 
Salah satu di antaranya Pavin Blok yang ada di Lorong I Jl. Allimbangeng yang kondisinya beberapa sudah terbongkar bahkan Pavinnya sudah banyak yang hilang, Berdasarkan wawancara dengan kepala keluarga yang tinggal di sekitarnya tempat tersebut mengatakan "Kami warga masyarakat yang temasuk dalam kelompok pemeliharaan prasarana telah beberapa kali mengadakan perbaikan paving blok tersebut tetapi pada saat hujan tiba paving-paving tersebut hancur, sehingga sampai saat ini kami membiarkan saja menunggu diadakannya pengaspalan seperti yang kami usulkan pada Musrembang beberapa waktu yang lalu" (wawancara dengan Bapak Alam pada tanggal 17 April 2014).

Sarana dan prasarana jalan merupakan hal yang paling sangat penting bagi setiap masyarakat sebagai prasarana transportasi dalam melakukan aktivitas setiap harinya. Sehingga apabila prasarana transportasi tersebut mengalami kerusakan atau tidak dapat digunakan sebagai mestinya maka dengan sendirinya akan menghambat sarana transportasi sehingga akan berdampak tidak lancarnya aktivitas warga yang menggunakan fasilitas tersebut. Sesuai dengan wawancara penulis kepada Lurah Cabenge mengenai hal tersebut diperoleh informasi bahwa pavin blok yang ada di Lorong I Jalan Allimbangeng sudah beberapa kali diperbaiki oleh warga masyarakat, tetapi hanya beberapa bulan saja bertahan. Menurutnya jalan tersebut sudah cukup lama usia pembangunan pavin bloknya hanya saja masih bisa dipergunakan sampai sekarang karena adanya kepedulian warga masyarakat disekitarnya untuk memperbaikinya. Lebih lanjut lurah menjelaskan bahwa dia sudah memproritaskan jalan tersebut untuk di adakan pengaspalan sesuai dengan usul warga masyarakat pada waktu Musrembang Kelurahan tetapi sampai sekarang pemerintah daerah belum ada tanda-tanda untuk diadakan pengaspalan, tetapi beliau akan terus memperjuangkannya sampai pemerintah daerah menyetujuinya karena jalanan tersebut sampai sekarang kondisinya masih rusak.

Partisipasi masyarakat di Kelurahan Cabenge dalam memelihara hasil-hasil pembangunan tidak terlepas dari peran serta Lurah Cabenge sebagai seseorang pemimpin terdekat dengan masyarakat dan paling sering bersentuhan langsung. Kepemimpinan Lurah Cabenge dalam menggerakkan warga untuk berpartisipasi dalam pemeliharaan hasil-hasil pembangunan sebagai salah satu langkah yang dinamis untuk mengantisipasi adanya kejadian yang tidak diinginkan terhadap pembangunan tersebut, misalnya terjadi kerusakan yang cepat sehingga penggunaannya tidak pula bertahan dalam jangka waktu yang lama.

Kepemimpinan Lurah Cabenge sudah mampu menggerakkan partisipasi masyarakat dalam memelihara hasil-hasil pembangunan tersebut. Dengan dibentuknya KPPM mendorong dengan sendirinya warga masyarakat untuk berpartisipasi memelihara hasil-hasil pembangunan dengan penuh rasa tanggung jawab yang tinggi serta terjalinnya kerjasama yang erat sesama anggota kelompok tersebut.

\section{Aktivitas atau kegiatan Lurah dalam Mengawasi Hasil Pembangunan}

Keikutsertaan masyarakat dalam pembangunan bukan hanya turut serta membantu dalam bentuk swadaya terhadap pelaksanaan pembangunan tetapi selain itu masyarakat di tuntut untuk terlibat dalam hal pengawasan baik pada saat pelaksanaan pembangunan berlangsung atau pegawasan terhadap hasil-hasil pembangunan yang telah selesai. Hal ini disebabkan karena selain telah menyumbang dalam bentuk swadaya masyarakat juga sebagai pemanfaat atau pengguna dari hasil-hasil pembangunan tersebut.

Ketertiban masyarakat dalam mengawasi pembangunan maupun hasil-hasilnya tidak terlepas dari kebijakan-kebijakan pemerintah khususnya pemerintah kelurahan untuk melibatkan masyarakat dari segi pegawasan atau hanya melibatkan masyarakat dalam proses pelaksanaannya saja, keterlibatan masyarakat dalam mengawasi pembangunan maupun hasil-hasilnya di Kelurahan Cabenge merupakan salah satu hasil kebijakan tersendiri yang diambil oleh bapak Lurah Cabenge, Hal ini berdasarkan wawancara Kepala Kelurahan Cabenge yang mengatakan : "Saya sudah informasikan kepada seluruh warga masyarakat baik itu pada acara rapat atau acara-acara lainnya bahwa kalau ada kejadian atau sesuatu yang menurut masyarakat tidak setuju langsung melaporkan kepada saya atau kepada Staf Kelurahan Cabenge baik itu di kantor atau dimanapun kami berada, Insya Allah kami akan menampung kemudian mengeceknya kalau memang benar kami akan tindak lanjuti kepada pihak yang bertanggung jawab atas pekerjaan tersebut". (wawancara pada tanggal 17 April 2014)

Pada dasarnya pengawasan yang dilakukan oleh masyarakat dalam pelaksanaan pembangunan atau hasil pembangunan tersebut sangat dibutuhkan oleh pemerintah kelurahan, karena selain terlibat langsung dalam proses pelaksanaannya mereka juga yang setiap harinya tinggal pada lokasi pembangunan tersebut sehingga mereka tahu persis kekurangan-kekurangan dalam pelaksanaan pembangunan tersebut ataukah pemanfaatan hasil pembangunan tersebut.

Berdasarkan hasil wawancara dengan bapak Lurah Cabenge pada tanggal 21 April 2014 didapat informasi bahwa beberapa minggu yang lalu sudah ada warga masyarakat yang melapor menyangkut pembangunan tempat sampah, menurutnya warga tersebut melaporkan tempat pembangunannya tidak sesuai dengan ukuran luas standar yang telah diinformasikan sebelumnya kepada warga, oleh pemborong dibangun kurang dari ukuran tersebut, kemudian menurutnya bapak lurah langsung mengecek di lapangan dan teryata memang benar ditemukan tidak sesuai dengan ukuran sehingga bapak lurah memberikan teguran dan memerintahkan kepada pemborongnya untuk membongkar kembali serta meyesuaikan sesuai dengan ukurannya.

Masyarakat biasanya enggan untuk melakukan pengawasan kepada proses pelaksanaan pembangunan ataupun hasil-hasilnya karena kebijakan-kebjakan pemerintah yang kurang mempedulikan keluhan atau 
laporannya, tetapi oleh bapak Lurah Cabenge setiap mendapat laporan atau keluhan dari masyarakat baik menyangkut masalah pemerintahan maupun pembangunan beliau langsung mengambil tindakan yang tegas jika memang benar-benar terbukti keluhan masyarakat tersebut.

Hal ini berdasarkan wawancara dari salah seorang tokoh pemuda Kelurahan Cabenge yang mengatakan : "Saya pernah melaporkan ke pak lurah mengenai pembuangan sampah di pinggir jembatan jalan Cabenge, dimana tempat tersebut tidak tepat digunakan sebagai tempat pembuangan sampah. Pada hari itu juga pak lurah langsung turun kelapangan yang selanjutnya menegur warganya kemudian memerintahkan untuk menjadikan jembatan tersebut sesuai dengan fungsinya". (wawancara dengan Bapak Abbas pada tanggal 22 April 2014)

Hal ini menunjukkan bahwa partisipasi masyarakat dalam mengawasi hasil pembangunan di Kelurahan Cabenge sudah terlaksana walaupun partisipasi tersebut perlu di tingkatkan dari waktu ke waktu. Masih rendahnya partisipasi masyarakat dalam mengawasi hasil pembangunan dapat terlihat pada buku keluhan pembangunan yang ada di Kantor Kelurahan Cabenge yang pada tahun 2014 ini hanya terdapat 2 (Dua) keluhan masyarakat diantaranya bangunan Posyandu Talabangie yang tidak sesuai dengan fungsi dan pemanfaatan yang di jadikan gudang oleh beberapa masyarakat.

Rendahnya partisipasi masyarakat dalam mengawasi pembangunan maupun pemanfaatan hasilnya salah satunya di sebabkan dari kurangnya waktu masyarakat yang tesedia, berdasarkan wawancara dari salah seorang tokoh masyarakat yang mengatakan bahwa "Saya memang jarang-jarang mengawasi pelaksanaan pembangunan atau pemanfaatan hasilnya karena waktu saya yang tidak memungkinkan, tetapi biasanya saya kalau berangkat kerja saya mengamati hasilnya yang sudah ada. Makanya saya biasanya menyumbang dana dalam pelaksanaan pembangunan ini". (Wawancara dengan Bapak H. Anto pada tanggal 25 April 2014)

Selain kurangnya waktu kebanyakan warga masyarakat sudah mempercayai pihak pemerintah kelurahan serta warga masyarakat yang lainnya yang menyumbangkan tenaga mereka dalam mengawasi proses pembangunan yang dilaksanakan Kelurahan Cabenge, menurut beberapa warga masyarakat yang diwawancarai, pemerintah Kelurahan sudah cukup ketat mengawasi jalannya pembangunan wilayah Kelurahan Cabenge karena setiap harinya pak Lurah Cabenge tampak mengamati pelaksanaan pembangunan tersebut selain itu ada juga warga masyarakat yang terlibat langsung dalam pembangunan tersebut sedangkan mengenai pengawasan hasil-hasil pemanfaatan pembangunan menurut warga masyarakat beberapa warga masyarakat tersebut sangat perlu diadakan pengawasan walaupun pemanfaatannya ditujukan kepada seluruh warga tetapi biasanya ada beberapa oknum atau warga masyarakat yang menyalahgunakannya sehingga merugikan warga masyarakat lainnya. Walaupun menurutnya di Kelurahan Cabenge masih jarang terjadi seperti ini tetapi kewaspadaan dan pengawasan harus tetap dilaksanakan.
Rendahnya partisipasi masyarakat dalam mengawasi pelaksanaan pembangunan dan hasil pembangunan di Kelurahan Cabenge memang sangat di sayangkan oleh bapak Lurah Cabenge, menurutnya dalam setiap kesempatan dia sering mengingatkan kepada warganya akan pentingnya pengawasan oleh warga masyarakat karena menurutnya pengawasan yang dilakukan warga masyarakat biasanya benar-benar sesuai dengan fakta di lapangan karena wargalah yang sebenarnya tahu persis akan kebutuhan mereka sendiri sehingga sangat membantu bagi pemerintah khususnya pemerintah kelurahan dalam mengambil sebuah kebijakan atau tindakan.

Kurangnya laporan dari warga masyarakat akan pelaksanaan pembangunan maupun pemanfaatan hasilhasil pembangunan menunjukkan bahwa partisipasi masyarakat dalam hal tersebut masih sangat rendah, Hal ini memang sangat mempengaruhi kepemimpinan Kelurahan Cabenge dalam menggerakkan masyarakat untuk berpartisipasi dalam pelaksanaan pengawasan pembangunan di wilayahnya.

\section{SIMPULAN}

Peranan Lurah Cabenge secara persuasif dalam meningkatkan partisipasi masyarakat terhadap pembangunan dapat dilihat dari aktivitas lurah, kepemimpinan Lurah Cabenge dengan cara membujuk dan mengajak masyarakat sudah dapat menggerakkan masyarakat untuk berpartisipasi terhadap pembangunan baik itu dalam acara formal misalnya rapat-rapat ataupun acara nonformal misalnya acara yasinan atau berdialog langsung dengan masyarakat. Selain itu kepemimpinan Lurah Cabenge dengan cara memberikan motivasi dalam bentuk pembebasan biaya administrasi di Kantor Lurah Cabenge mendorong tingginya partisipasi masyarakat terhadap pembangunan.

Peranan Lurah secara akomodatif dalam meningkatkan partisipasi masyarakat terhadap pembangunan dapat dilihat dari aktivitas lurah dalam memberikan informasi baik pada papan informasi di kelurahan maupun acara formal dan non formal mengenai masalah pembangunan sudah dapat mendorong masyarakat untuk berpartisipasi terhadap pembangunan. Selain itu aktivitas lurah dalam menerima aspirasi masyarakat sudah cukup aktif tapi partisipasi masyarakat dalam mengeluarkan ide atau gagasan menyangkut masalah pembangunan masih cukup rendah dapat dilihat dari kurangnya masyarakat yang hadir dalam acara musrembang dan kurangnya masyarakat yang mengeluarkan ide atau aspirasinya.

Peranan Lurah Cabenge secara Dinamis Antisipatif dalam meningkatkan partisipasi masyarakat terhadap pembangunan dapat kita lihat dari aktivitas Lurah yang cukup berhasil dalam menggerakkan masyarakat memelihara hasil pembangunan. Selain itu Kepemimpinan Lurah secara akomodatif dapat kita lihat juga dari aktivitas lurah dengan dalam menggerakkan masyarakatnya untuk mengawasi penggunaan hasil-hasil pembangunan dengan memberikan tanggung jawab penuh kepada 
masyarakat di Kelurahan Cabenge yang masih kurang dalam menggerakkan partisipasi masyarakat tersebut.

\section{Saran}

1. Diharapkan kepada Lurah Cabenge untuk tetap mempertahankan pemberian motivasi dalam bentuk pembebasan biaya administrasi kepada masyarakat yang benar-benar aktif berpartisipasi terhadap pembangunan sehingga ada dorongan bagi masyarakat yang belum aktif berpartisipasi terhadap pembangunan.

2. Pemberian informasi kepada masyarakat terkait dalam kegiatan pembangunan oleh bapak Lurah Cabenge diharapkan secara terperinci dengan jelas dan cepat sehingga masyarakat dapat lebih cepat mengetahui pelaksanaan pembangunan.

3. Diharapkan agar dapat melibatkan seluruh lapisan masyarakatnya kemudian memberikan tanggung jawab penuh kepada mereka dalam mengawasi pemanfaatan hasil pembangunan serta diharapkan juga kepada bapak Lurah Cabenge untuk segera mengambil tindakan ketika ada laporan dari warga mengenai penyalahgunaan serta memberikan sanksi yang sesuai dengan perbuatan masyarakat tersebut.

\section{DAFTAR PUSTAKA}

Adisasmita, Raharjo, 2006, Membangun Desa Partisipatif, Graha Ilmu, Jogjakarta.

Kartono, Kartini, 2003, Pemimpin Dan Kepemimpinan, Raja Grafindo Persada, Jakarta.

Koentjaraningrat, 1985, Metode-Metode Penelitian Masyarakat, Gramedia, Jakarta.

Marbun, B.N, 1980, Proses Pembangunan Desa Menyongsong Tahun 2000, Erlangga, Jakarta.

Moeljarto, T, 1987, Politik Pembangunan : Sebuah Analisis Konsep, Arahan Dan Strategi, P.t. Tiara Wacana, Yogyakarta.

Ndraha, Taliziduhu, 1987, Partisipasi Masyarakat Desa Dalam Pembangunan Di Beberapa Desa, Yayasan Karya Darma IIP, Jakarta.

Rivai, Veithzal, 2007, Kepemimpinan Dan Perilaku Organisasi, PT. Raja Garfindo Persada, Jakarta.

Siagian, Sondang P, 2000, Proses Pengelolaan Pembangunan, PT. Gunung Agung, Jakarta.

Supriatna, Tjahya, 1995, Stimulan Pemerintah Dalam Rangka Meningkatkan Partisipasi Masyarakat Di Bidang Pembangunan Desa, Yayasan Karya Dharma, Jakarta. 